\title{
A systematic review and meta-analysis of the gonadotoxic effects of cyclophosphamide and benefits of gonadotropin releasing hormone agonists (GnRHa) in women of child-bearing age with autoimmune rheumatic disease
}

\author{
Shi-Nan Luong, Anthony Isaacs, Zhixin Liu, Fang E Sin \& Ian Giles
}

To cite this article: Shi-Nan Luong, Anthony Isaacs, Zhixin Liu, Fang E Sin \& lan Giles (2020):

A systematic review and meta-analysis of the gonadotoxic effects of cyclophosphamide and benefits of gonadotropin releasing hormone agonists $(\mathrm{GnRHa})$ in women of child-bearing age with autoimmune rheumatic disease, Expert Review of Clinical Immunology, DOI:

10.1080/1744666X.2020.1724091

To link to this article: https://doi.org/10.1080/1744666X.2020.1724091

Accepted author version posted online: 31 Jan 2020.

\section{Submit your article to this journal $\sqsubset$}

Џ Article views: 5

Q View related articles $\longleftarrow$

View Crossmark data ¿ 
Publisher: Taylor \& Francis \& Informa UK Limited, trading as Taylor \& Francis Group

Journal: Expert Review of Clinical Immunology

DOI: $10.1080 / 1744666 X .2020 .1724091$

A systematic review and meta-analysis of the gonadotoxic effects of cyclophosphamide and benefits of gonadotropin releasing hormone agonists (GnRHa) in women of child-bearing age with autoimmune rheumatic disease

Shi-Nan_Luong ${ }^{1,2,3}$, Anthony Isaacs ${ }^{1}$, Zhixin Liu ${ }^{4}$, Fang E Sin ${ }^{1}$, lan Giles ${ }^{1,2}$

1. Department of Rheumatology, University College London Hospital, London NW1 2BU, United Kingdom

2. Centre for Rheumatology Research, Division of Medicine, University College London, Department of Medicine, Rayne Institute, 5 University Street, London WC1E 6JF, United Kingdom

3. South Western Sydney Clinical School, Faculty of Medicine, University of New South Wales 2052, Sydney, Australia.

4. Stats Central, Mark Wainwright Analytical Centre, University of New South Wales 2052, Sydney, Australia

\section{Corresponding author:}

Shi-Nan Luong

Rayne Institute, Centre for Rheumatology Research

5 University St

London WC1E 6JF

United Kingdom

Email: s.luong@ucl.ac.uk

Running title: Systematic review of $\mathrm{CYC}$ and $\mathrm{GnRHa}$ in autoimmune rheumatic disease 


\section{Abstract:}

Objectives: To systematically review the risk of sustained amenorrhoea with intravenous (IV) cyclophosphamide in autoimmune rheumatic disease (ARD), and evaluate the efficacy of gonadotropin releasing hormone agonists ( $\mathrm{GnRHa})$ to reduce this risk.

Methods: Systematic search for papers reporting the incidence of sustained amenorrhoea $\geq 12$ months in ARD following: IV cyclophosphamide; or GnRHa and IV cyclophosphamide compared to IV cyclophosphamide alone.

Results: From 31 articles and 1388 patients with a mean age of 27.7 years, sustained amenorrhoea occurred in 273 patients (19.7\%). Of 56 patients (mean age range 23.9-25.6 years) receiving $\mathrm{GnRHa}$ and IV cyclophosphamide, and 37 controls (mean age range 25-30.1 years) given IV cyclophosphamide only, sustained amenorrhoea occurred in 2/56 (3.6\%) patients treated with GnRHa, compared to $15 / 37(40.5 \%)$ controls. Pooled odds ratio of sustained amenorrhoea with $\mathrm{GnRHa}$ and cyclophosphamide versus cyclophosphamide alone was 0.054 (95\% Cl 0.0115$0.2576 \mathrm{p}<0.001)$, corresponding to a number needed to treat of $2.7(95 \% \mathrm{Cl} 1.955-$ $4.388)$ and absolute risk reduction of $36.95 \%$ (95\% Cl $35.6-38.4 \%)$.

Conclusion: Sustained amenorrhoea with IV cyclophosphamide was observed in patients with ARD, especially with increasing age and cumulative doses $>5 \mathrm{~g}$. GnRHa reduced this risk and should be considered with IV cyclophosphamide in women of childbearing age with ARD.

Keywords: Sustained amenorrhoea, cyclosphosphamide, gonadotropin releasing hormone agonists, rheumatic disease 


\section{Introduction}

Cyclophosphamide remains the gold standard treatment in many organ or lifethreatening manifestations of autoimmune rheumatic disease (ARD) such as systemic lupus erythematosus (SLE) or primary systemic vasculitis. Use of oral cyclophosphamide in ARD has been largely superseded by intravenous (IV) administration because of its superior safety profile [1-3]. Gonadal toxicity however, with long-term consequences on fertility in women of reproductive age remains a significant concern [3], especially in women with ARD who already have reduced fertility compared to the normal population [4]. Therefore, attempts have been made to further reduce IV cyclophosphamide toxicity by lowering the cumulative dose in treatment protocols [5].

Throughout female reproductive life, there is a balance between ovarian follicles in quiescent (primordial) and growing stages, an equilibrium that depends on gonadotropins [6]. In chemotherapy-induced gonadal toxicity, there is damage to all ovarian follicular stages and cell types [6]. Gonadotropin releasing hormone agonists ( $\mathrm{GnRHa}$ ) are a treatment option alongside cyclophosphamide, to reduce ovarian toxicity and the rate of sustained amenorrhoea. There are various theories, some controversial, regarding their underlying mechanism including: i) GnRHa stimulate gonadotropin release which leads to desensitisation of $\mathrm{GnRH}$ pituitary receptors, inducing a transient hypogonadotropic pre-pubertal milieu and maintaining ovarian follicles in a quiescent state (the primordial stage) in which the follicles are less vulnerable to cyclophosphamide-induced gonadotoxicity; ii) GnRHa may decrease apoptosis [6, 7] and mitochondrial stress via its direct effect on $\mathrm{GnRH}$ receptors in the ovaries [6]; or iii) GnRHa decrease utero-ovarian blood flow and therefore cyclophosphamide dose to ovarian follicles [6, 8]. Furthermore, growing follicles normally produce anti-mullerian hormone $(A M H)$, which negatively affects the recruitment of primordial follicles into the growing pool $[6,7]$. Chemotherapy agents cause damage to growing follicles, a reduction in $\mathrm{AMH}$, and subsequently more primordial follicles are recruited into the growing pool [6]. GnRHa prevent damage to growing follicles that normally produce $\mathrm{AMH}$, limiting the gonadotoxic effect of chemotherapy $[6,7]$. .

The ovarian protective effects of $\mathrm{GnRHa}$ in patients have been demonstrated in various meta-analyses of patients undergoing multidrug gonadotoxic chemotherapy for malignancies including breast cancer [11-13] and possibly in lymphoma [13]. Furthermore, in breast cancer patients undergoing chemotherapy, a systematic review found that $\mathrm{GnRHa}$ led to a $50 \%$ reduction in the risk of premature ovarian insufficiency [15]. Along with counselling about other fertility preservation methods such as embryo cryopreservation $[16,17]$, discussion about the use of $\mathrm{GnRHa}$ is now part of routine care in pre-menopausal breast cancer patients undergoing chemotherapy $[15,18]$. GnRHa have limited, usually reversible side effects including hot flushes, headaches, sweating, and vaginal dryness [16]. However, the risk of cyclophosphamide induced ovarian dysfunction and the potential benefit of $\mathrm{GnRHa}$ found in patients with malignant diseases exposed to high dose regimes of cyclophosphamide, may not be directly comparable to patients with ARD. In 
particular, patients with ARD may be exposed to lower cumulative doses of cyclophosphamide and fewer other gonadotoxins used in chemotherapy regimens. Additionally lupus patients may be particularly at risk, as they appear to have low ovarian reserve regardless of cyclophosphamide [19-21]. However, relevant information on the use of GnRHa and cyclophosphamide in patients with ARD has been thus far mostly been obtained from small cohort studies, and/or combined analyses with other patients receiving cyclophosphamide for malignancies.

Therefore, there is a need to more precisely categorise the risk of gonadal toxicity in patients with ARD, and determine whether $\mathrm{GnRHa}$ are effective in patients with nonmalignant disease. Consequently, we performed a systematic review and metaanalysis with the aim of answering two questions: 1) What is the risk of sustained amenorrhoea in women treated with IV cyclophosphamide for ARD? and 2) Are $\mathrm{GnRHa}$ effective in reducing this risk?

\section{Materials and methods}

\subsection{Publication search and selection of studies}

Using Preferred Reporting Items for Systematic Reviews and Meta-Analyses (PRISMA) principles [22], we performed a search of published English language papers in Pubmed, EMBASE, MEDLINE and the Cochrane Library from database inception until April 2018. The outcome measure used to assess premature ovarian insufficiency (POI) was sustained amenorrhoea, defined as more than 12 months of cessation of menstruation after treatment with IV cyclophosphamide.

Studies were identified by searching databases using combinations of the key MESH and free terms. On the advice from University College London Library staff, the search strategy used for Pubmed, EMBASE and MEDLINE was (cyclophosphamide) AND (gonadal toxicity OR premature ovarian failure OR amenorrhoea OR ovarian failure OR ovarian OR ovary OR infertility) AND (rheumatic OR rheumatology OR lupus OR SLE OR systemic lupus erythematous OR vasculitis OR autoimmune OR glomerulonephritis) and for GnRHa use we added AND (gonadotropin releasing hormone agonist OR GnRH OR GnRH-a). Due to its comparatively smaller database, the search strategy for Cochrane was kept broader to ensure studies were not missed and involved the search term (cyclophosphamide), and for GnRHa use the search term was (gonadotropin hormone releasing hormone agonist).

Two authors independently reviewed each study abstract identified from the searches and selected relevant papers based on the inclusion criteria of: ARD; IV cyclophosphamide; incidence reported of sustained amenorrhoea; and cohort more than 5 patients. Exclusions were: non-English language articles; abstracts; non-ARD patients unless their data could be separated from that of ARD patients; and use of oral cyclophosphamide unless this data could be separated from that of IV cyclophosphamide. To assess the use of $\mathrm{GnRHa}$, the inclusion criteria were: $\mathrm{GnRHa}$ use in ARD during treatment with IV cyclophosphamide; an IV cyclophosphamide alone control group; and reported incidence of sustained amenorrhoea. Study 
authors were contacted where further information was needed, which was included where received.

\subsection{Data collection process}

A data extraction sheet was developed, its reliability examined on 10 studies and then refined to ensure all relevant data were captured. Two authors extracted and independently checked the data. Disagreements were resolved by group discussion. Each selected article was systematically examined to note the following study characteristics.

2.3 Patient population: studies were selected that included more than five patients with ARD treated with IV cyclophosphamide +/- GnRHa. The mean cohort age was noted as well as study type and duration.

2.4 Intervention: information was gathered on the mean IV cyclophosphamide dose per cohort and in those patients who experienced sustained amenorrhoea.

2.5 Comparison: was made of patients with ARD treated with IV cyclophosphamide who experienced sustained amenorrhoea and those who did not, as well patients with ARD treated with IV cyclophosphamide +/- GnRHa.

2.6 Outcome: was sustained amenorrhoea (>12 months) and variables used to assess this risk due to IV cyclophosphamide +/- GnRHa were: mean cohort age; mean IV cyclophosphamide cohort dose; incidence of sustained amenorrhoea; mean age of patients with sustained amenorrhoea; mean age of patients without sustained amenorrhoea; mean IV cyclophosphamide dose of patients with sustained amenorrhoea; and mean IV cyclophosphamide dose in patients without sustained amenorrhoea. Information was also gathered where available on: method of ensuring adequate menstruation pre-treatment; hormonal confirmation of sustained amenorrhoea; and pregnancy data post-treatment. Outcome bias was assessed at the analysis stage and is presented in the discussion. The strength of evidence of each study was assessed using the GRADE (Grading of Recommendations, Assessment, Development and Evaluations) framework [23].

\subsection{Statistical analysis}

Medcalc Version 15.8 was used to assess the odds ratio of sustained amenorrhoea compared to controls. R Version 3.5.1 was used for the meta-analysis using the metafor package. The random effects meta-analysis model was used to obtain the overall summary estimate of the proportion of sustained amenorrhoea across studies. Freeman-Tukey double arcsine transformation was used to stabilise the variance of individual studies where the proportion was close to the margin of 0 or 1 . Heterogeneity was quantified by $I^{2}$ statistics. The evidence of bias was assessed through visual inspection of funnel plots and regression test. Meta-regression analysis was further performed to examine the possible sources of heterogeneity, 
and the association between study factors and the proportion of sustained amenorrhoea.

\section{Results:}

3.1 Study and patient characteristics: An initial search revealed 1446 articles. After the removal of duplicate articles, 1158 articles were screened. Studies were excluded for various reasons including: study outcome not within the scope of this systematic review; article not available in the English language; or full text article not available to review. Ninety three papers were selected for full text review, from which 31 studies were identified that addressed the risk of sustained amenorrhoea with IV cyclophosphamide (Figure 1). These studies examined 1388 patients with ARD (Table 1) [5, 10, 19, 24-49]. The studies included patients with: SLE ( $n=1332$ ); granulomatosis with polyangiitis $(n=20)$; undifferentiated systemic vasculitis $(n=12)$; polyarteritis nodosa, microscopic polyangitis or eosinophilic granulomatosis with polyangiitis ( $n=11$, note no further breakdown available on diagnoses in this study) $[25,33]$; idiopathic inflammatory myopathy $(n=4)$; systemic sclerosis $(n=3)$; Behcet's disease $(n=1)$; juvenile idiopathic arthritis $(n=1)$; mixed essential cryoglobulinaemia $(n=1)$; panniculitis $(n=1)$; relapsing polychondritis $(n=1)$; and Takayasu's arteritis $(n=1)$.

The studies consisted of: 13 retrospective cohort studies; 4 retrospective casecontrol studies; 2 retrospective cross-sectional studies; 6 prospective cohort studies; 1 mixed retrospective and prospective cohort study; and 5 randomised controlled trials.

\subsection{Increasing patient age and total dose of IV cyclophosphamide determine risk of sustained amenorrhoea}

Sustained amenorrhoea occurred in $n=273$ patients $(19.7 \%$, range across the studies $0-66.7 \%$ depending on age and cumulative cyclophosphamide dose). Twenty studies provided information on cumulative cyclophosphamide dose, usually reported as a mean dose. The rate of sustained amenorrhoea was positively correlated with increasing cumulative cyclophosphamide dose (Figure 2). The majority of cases of sustained amenorrhoea occurred in patients receiving a cumulative cyclophosphamide dose $>5 \mathrm{~g}$.

In two studies, sustained amenorrhoea occurred at cumulative doses $<5 \mathrm{~g}$. Baba et al found a $12.5 \%$ rate $(4 / 29)$ of sustained amenorrhoea at a median cumulative cyclophosphamide dose of $1 \mathrm{~g}$ [24]. However, all patients who developed sustained amenorrhoea in this study were above 40 years of age, thus confirming that age is an important risk factor [24]. Similarly Houssiau et al found a $4.9 \%$ rate (2/41) of sustained amenorrhoea with a mean cumulative cyclophosphamide dose of $3 \mathrm{~g}$; both of these affected patients were 44 years old [5]. Therefore, a low cumulative dose of IV cyclophosphamide $(<5 \mathrm{~g})$ is less likely to induce sustained amenorrhoea in patients under 40 . 
Five studies, mainly comprising patients with SLE, found higher doses of cumulative cyclophosphamide (in grams) were associated with sustained amenorrhoea in patients with ARD, compared to those with ongoing menstruation $(9.4 \mathrm{~g}$ vs $8.4 \mathrm{~g}$ $p<0.05$ [30], $16.8 \mathrm{~g}$ vs $11.8 \mathrm{~g} p>0.05$ [32], $20.8 \mathrm{~g}$ vs $13.4 \mathrm{~g} p<0.05$ [36], $18.9 \mathrm{~g}$ vs $9.1 \mathrm{~g}$ $p<0.05$ [47] and $18.6 \mathrm{~g}$ vs $9.8 \mathrm{~g} p$ value not provided [10]. Laskari et al found sustained amenorrhoea occurred in $51.2 \%$ of women receiving a mean cumulative cyclophosphamide dose of $20.1 \mathrm{~g}$, compared to $4.8 \%$ of those receiving $8.1 \mathrm{~g}$ [28]. One study found sustained amenorrhoea developed in $12 \%$ of patients after seven monthly cyclophosphamide pulses of 0.5 to $1.0 \mathrm{~g} / \mathrm{m}^{2}$ body surface area, and $39 \%$ of patients after fifteen monthly pulses of 0.5 to $1.0 \mathrm{~g} / \mathrm{m}^{2}$ body surface area [26]. Another study found that a mean dose of $0.9 \mathrm{~g} /$ pulse (range $0.5-1 \mathrm{~g}$ ) of cyclophosphamide produced rates of sustained amenorrhoea of: $0 \%$ in patients less than 26 years of age; $20 \%$ in patients aged $26-35$ years (all $\geq 8$ pulses); $50 \%$ in patients age $36-40$ years receiving $\leq 7$ pulses; and $100 \%$ in those greater than 40 years of age receiving $\geq 8$ pulses [33].

In addition, several studies found an increased incidence of sustained amenorrhoea with increasing patient age (Figure 3). The most detailed evidence of this association came from three studies; one demonstrating sustained amenorrhoea in $12 \%$ of patients $<25$ years of age, $27 \%$ in patients age $26-30$ years and $62 \%$ in patients age $>31$ years [26]. Two other studies reported incidence of sustained amenorrhoea according to age of: $27.3 \%$ in patients aged $<30$ years, $56.3 \%$ in patients age $30-39$ years, and $87.5 \%$ in patients $\geq 40$ years of age [32]; and $12.1 \%$ in SLE patients $<30$ years and $39.1 \%$ in SLE patients $>30$ years [33]. Several other studies also clearly distinguished the relationship between the incidence of sustained amenorrhoea and patient's age: $0 \%$ with a mean age of 13 years [37, 40], $11.4 \% \leq 31$ years and $69.6 \%$ $\geq 32$ years [34]. In one study, 4/29 patients who developed sustained amenorrhoea were all $\geq 40$ years [24].

The combination of increasing patient age and cumulative dose of IV cyclophosphamide increases the incidence of sustained amenorrhoea. In particular, one study found the risk of sustained amenorrhoea in patients $>32$ years of age to increase with total cumulative cyclophosphamide such that it was: $33 \%$ at $>5 \mathrm{~g} / \mathrm{m}^{2}$; $50 \%>8 \mathrm{~g} / \mathrm{m}^{2}$; and $90 \%$ above $12 \mathrm{~g} / \mathrm{m}^{2}$ [34]. A separate study found the incidence of sustained amenorrhoea to be: $0 \%$ at all ages with cumulative cyclophosphamide dose of $<5 \mathrm{~g} ; 0 \%$ at age $<20$ years with cumulative dose of cyclophosphamide up to $15 \mathrm{~g} ; 16.7 \%$ age $21-30$ years receiving $>10 \mathrm{~g} ; 17 \%$ and $29 \%$ respectively for those aged $31-40$ receiving $5-10 \mathrm{~g}$ and $10-15 \mathrm{~g}$; and $33 \%, 100 \%$ and $100 \%$ respectively for those age $>40$ years receiving $5-10 \mathrm{~g}, 10-15 \mathrm{~g}$ and $>15 \mathrm{~g}$ [30]. One other study however, reported risk at a lower age in a 19 year old who developed sustained amenorrhoea after a cumulative dose of $14.4 \mathrm{~g}$ of IV cyclophosphamide [28].

\subsection{Meta-analysis}


A meta-analysis of the proportion of sustained amenorrhoea was undertaken on 17 studies ( $n=671$ patients) that provided the required data for meta-analysis purposes (Figure 4). The pooled estimate of sustained amenorrhoea based on a random effects model was 0.20 (95\% Cl: $0.14-0.28)$. There was considerable heterogeneity between studies $\left(I^{2}=79 \%\right)$. This heterogeneity was not surprising as the studies had diverse methodology; patient cohorts were from different countries and ethnic backgrounds; and the majority of patients had SLE, which is a heterogeneous disease with different disease manifestations. Mixed effect meta-regression found that the rate of sustained amenorrhoea was positively associated with increasing mean age of study cohort $((\beta=0.02,95 \% \mathrm{Cl}(0.005-0.04), \mathrm{p}=0.01))$ and higher IV cyclophosphamide dose $((\beta=0.03,95 \% \mathrm{Cl}(0.01-0.04), p<0.0001))$. There was no significant association observed between the type of ARD and the rate of sustained amenorrhoea at a significance level of $0.05(p=0.09)$, however, this result probably reflects the low numbers of patients with diseases other than SLE. Of the 671 patients, there were 664 SLE patients, but only 2 systemic sclerosis patients, 1 Behcet's patient, 1 juvenile idiopathic arthritis patient, 1 relapsing polychondritis patient, 1 granulomatosis with polyangiitis patient and 1 Takayasu's arteritis patient. The visual inspection of funnel plot (Figure 5 ) and regression test for asymmetry did not reveal significant asymmetry $(z=0.2236, p=0.8231)$. This suggests a trend against reporting bias.

\subsection{Successful pregnancy following IV cyclophosphamide}

To further assess the potential impact of IV cyclophosphamide on fertility we considered pregnancy outcomes where stated in the selected studies. In their study, Boumpas et al assigned lupus nephritis patients randomly to either 7 or $\geq 15$ monthly pulses of IV cyclophosphamide, and also included neuropsychiatric lupus patients who received a course of cyclophosphamide equivalent to the shorter course of cyclophosphamide [26]. The study reported 8 pregnancies (4 full term pregnancies with delivery of normal babies and 4 elective abortions) in a cohort with a mean age of 27 years treated with 7 monthly pulses of IV cyclophosphamide of 0.5 to $1.0 \mathrm{~g} / \mathrm{m}^{2}$ body surface area, and no pregnancies reported in the group who had 15 pulsed infusions at a similar dose [26]. Pregnancies reported in this study occurred after cyclophosphamide treatment, thus suggesting that women who do not develop amenorrhoea remain fertile [26]. Mitwalli et al found 3/39 patients had viable pregnancies following 24 pulses of treatment of $5 \mathrm{mg} / \mathrm{kg}$ cyclophosphamide, in a cohort with a mean age of 30.3 years [29]. Langevitz et al noted 5 successful conceptions in 4 patients with a mean age at birth of 27.2 (range of cumulative cyclophosphamide dose in these patients $1.6-6.7 \mathrm{~g}$ ), resulting in the delivery of 5 full term healthy babies [41]. Park et al described $17 / 17$ successful pregnancies in 13 patients, in a cohort with a mean age of 31.1 years and mean cumulative dose of cyclophosphamide of $9.0 \mathrm{~g}$ [30]. However, no patients with sustained amenorrhoea who tried to conceive fell pregnant; notably the proportion of the overall cohort trying to conceive was not reported [30]. Blumenfeld et al reported 3 successful 
pregnancies in a cohort with a mean age of 30.1, receiving a mean cumulative cyclophosphamide dose of $10.5 \mathrm{~g}$ [50]. Somers et al found 3 successful pregnancies, in a cohort with a mean age of 25 and mean cumulative cyclophosphamide dose of $12.9 \mathrm{~g}$ [51]. Massenkeil et al found $4 / 4$ patients who tried to conceive were successful and gave birth to 6 healthy children. $2 / 4$ patients had to use in vitro fertilisation, and $2 / 4$ had 3 spontaneous conceptions [10]. Alarfaj et al found that $48 / 99$ patients conceived, resulting in 90 pregnancies consisting of 29 foetal losses and 61 live births [45]. The mean cumulative cyclophosphamide dose and mean age was significantly lower in patients who conceived successfully, compared to those who did not fall pregnant $(6.7 \mathrm{~g}$ and 28.3 years vs $8.3 \mathrm{~g}$ and 34.1 years respectively, $p<0.05$ for both dose and age) [45].

\subsection{GnRHa co-treatment during IV Cyclophosphamide for Rheumatic Disease}

Three studies examined the use of $\mathrm{GnRHa}$ with IV cyclophosphamide treatment in $n=93$ ARD patients with the following diagnoses: SLE $(n=85)$, systemic sclerosis $(5)$, mixed connective tissue disease $(n=2)$, polyarteritis nodosa $(n=1)$, juvenile idiopathic arthritis $(n=1)$ and Behcet's Disease $(n=1)$ (Table 2) [50-52]. These studies included: one retrospective case-control study [50]; one study with prospective data collection for cyclophosphamide plus $\mathrm{GnRHa}$ treated patients and retrospective cyclophosphamide only control data [51]; and one prospective cohort study [52]. Two of the studies were from the same centre, but presumably had different cohorts of patients based on the demographic and clinical data provided by the authors $[50,52]$.

Of these patients, 56 received GnRHa plus IV cyclophosphamide and 37 received IV cyclophosphamide only. In all three studies, the mean age (years) in the GnRHa treated patients was lower in each of the three $\mathrm{GnRHa}$ groups than that of the controls (25.6 \pm 5.3 vs $30.1 \pm 5.5, p=0.04$ [50]; $23.9 \pm 1.0$ vs $25.6 \pm 0.9, p>0.05$ [51]; and 25.6 vs 28.2, p value not provided [52]. The mean cumulative dose (in grams) used in the GnRHa group was lower than the controls in two studies (8.92 vs 10.52, p value not provided [50]; and 7.7 vs 13.3, p value not provided and data missing from 3 patients [52]). For the other study, cumulative cyclophosphamide dose was the same in both groups at $12.9 \pm 0.5[51]$.

Sustained amenorrhoea occurred in 2/56 (3.6\%) patients treated with $\mathrm{GnRHa}$, compared to $15 / 37(40.5 \%)$ of controls [50-52]. Somers et al found one patient developed sustained amenorrhoea despite GnRHa treatment [51]. However, this patient was in the 75th percentile for age (28.2 years) and 99th percentile for cumulative cyclophosphamide dose $(33.5 \mathrm{~g})$ for their cohort [51]. The one patient on GnRHa who developed sustained amenorrhoea in Blumenfeld et al's 2011 study was aged 37 years [50]. The pooled odds ratio of ovarian dysfunction with $\mathrm{GnRHa}$ and cyclophosphamide compared to cyclophosphamide alone was $0.054(95 \% \mathrm{Cl}$ $0.0115-0.2576 p=0.0002$, z-statistic 3.668), corresponding to a number needed to treat (NNT) of $2.7(95 \% \mathrm{Cl} 1.955-4.388)$ and an absolute risk reduction of $36.95 \%$ (95\% Cl 35.6-38.4\%). 


\section{Discussion}

We found that the incidence of sustained amenorrhoea increased with increasing cumulative dose of IV cyclophosphamide and increasing age in patients with ARD. $\mathrm{GnRHa}$ significantly reduced the risk of sustained amenorrhoea in patients with ARD treated with mean cumulative cyclophosphamide doses ranging from 7.7 to $12.9 \mathrm{~g}$. This ovarian protective effect is in keeping with results achieved in patients receiving IV cyclophosphamide and $\mathrm{GnRHa}$ for malignancies, with various meta-analyses supporting its use in breast cancer $(\mathrm{OR}$ of $\mathrm{POI}=0.36,95 \% \mathrm{Cl} 0.23-0.57, \mathrm{p}<0.001$ [11]; and $\mathrm{OR}$ of $\mathrm{POI}=0.38,95 \% \mathrm{Cl} 0.26-0.57, \mathrm{p}<0.001$ [12] when comparing those who received $\mathrm{GnRHa}$ vs those who did not), although no significant benefit was seen in lymphoma patients (RR 0.70, 95\% Cl 0.20-2.47) [13]. .

The incidence of sustained amenorrhoea in our analysis became apparent at cumulative doses of IV cyclophosphamide of $1 \mathrm{~g}$ or more, albeit in patients over 40 years, with most studies showing sustained amenorrhoea at doses $>5 \mathrm{~g}$. The incidence of sustained amenorrhoea increased in direct correlation to increasing IV cyclophosphamide dose. A similar relationship was observed with increasing age, although several studies report sustained amenorrhoea in patients with ARD at 2030 years of age [26, 27, 35, 51]. This finding is particularly relevant in SLE, since previous studies have identified low ovarian reserve in these patients [19-21]. Of further concern to younger patients is the possibility that they may require additional doses of cyclophosphamide to treat refractory or recurrent disease, which may further diminish already depleted ovarian follicle numbers. It remains difficult however, to risk stratify an ARD cohort by age that one can be certain is not at risk of sustained amenorrhoea when considering IV cyclophosphamide. This consideration is important because the consequences of gonadal toxicity and $\mathrm{POI}$ in young women include infertility, premature osteoporosis, atherosclerosis, mood disorders and cardiovascular mortality [42, 53-55]. Our findings however, do provide reassurance that cumulative doses of cyclophosphamide below $5 \mathrm{~g}$ are unlikely to produce sustained amenorrhoea in patients with ARD under 40 years of age.

Findings of this systematic review are limited by the included studies that are mostly retrospective; lack disease controls; have few or no patients with diseases other than SLE; and report mean cohort age and cyclophosphamide dose with different cyclophosphamide dosing regimens that make direct comparison difficult. In addition, the effect of chronic disease on ovarian function was considered in some, but not all studies in multivariate analysis $[30,37]$.

Overall, we confirmed a protective effect of $\mathrm{GnRHa}$ in patients with ARD treated with IV cyclophosphamide. GnRHa are more convenient to administer than alternative ovarian preservation techniques, such as embryo and oocyte cryopreservation [56], and the latter techniques do not prevent the risk of chemotherapy-induced POI [6]. Hormonal treatment with the combined oral contraceptive has also been studied in conjunction with chemotherapy, but has failed to prove beneficial, despite its early 
promise $[57,58]$. One potential drawback however of $\mathrm{GnRHa}$ therapy is that it can take up to 22 days to achieve full ovarian suppression after an initial stimulatory effect on the ovaries, and ideally should be given well in advance of the administration of chemotherapy [59].

Limitations of the studies reporting the use of $\mathrm{GnRHa}$ include the small number of studies, small cohort numbers, and possible selection bias with older patients used in the control group raising doubt as to the magnitude of their efficacy. However, the mean age group in both $\mathrm{GnRHa}$ and control groups was 30 or under in all studies. Furthermore this finding may reflect the fact that older patients are not routinely being offered $\mathrm{GnRHa}$, yet they are the age group most at risk of sustained amenorrhoea due to the effects of ageing on ovarian reserve. Indeed this finding is becoming ever more pertinent as the average age of women giving birth in the UK continues to rise, with the average age now 30.5 years in 2017 compared to 28.5 years in 2000 [60].

Another consideration when interpreting these studies is their use of menstruation as a surrogate marker of ovarian function, since functional impairment of ovarian function may exist despite normal menstrual cycles [20]. Therefore, reliance upon sustained amenorrhoea may underestimate or overestimate the protective effect of $\mathrm{GnRHa}$ on ovarian function. Furthermore, many of the studies were retrospective, so significant recall bias regarding return of menstruation may be a confounding factor. In addition, sustained amenorrhoea is not always indicative of permanent POI [61]. The gold standard outcome would be to measure hormonal markers of ovarian function such as follicular stimulating hormone or anti-mullerian hormone and carry out ovarian ultrasound to measure follicular reserve post IV cyclophosphamide [20]; this procedure however was only performed in only $2 / 31$ studies included in our systematic review [50,52]. Although an additional 9/31 studies measured hormone levels, often to confirm POI in cases of sustained amenorrhoea, [10, 19, 27, 31, 32, $43,47,49,51$ ], only 4 of those studies provided specific results or exact levels (see Table 1) $[10,19,47,49]$ and is another limitation of our systematic review and metaanalysis. Another indication of fertility is the occurrence of a successful pregnancy and although we have included the available evidence, the reports are limited and do not state the proportion of patients trying to conceive.

Despite these limitations, the effectiveness of $\mathrm{GnRHa}$ is still very promising, with a large absolute risk reduction that cannot be fully explained by methodological or selection bias. A recent phase 3 randomised control trial of the $\mathrm{GnRHa}$ leuprolide undertaken by McCune et al unfortunately had to be terminated, presumably as only 7 patients were recruited [62]. Therefore, there still remains a pertinent need for larger, better quality studies assessing GnRHa use in ARD.

\section{Conclusion}


In conclusion we found a significant risk of ovarian toxicity manifested by sustained amenorrhoea, after therapy with IV cyclophosphamide in patients with ARD of various reproductive ages, particularly when receiving cumulative doses of greater than $5 \mathrm{~g}$. Concomitant therapy with $\mathrm{GnRHa}$ was highly effective in preventing sustained amenorrhoea, and should be offered to all premenopausal women with ARD before receiving IV cyclophosphamide treatment in non-urgent situations.

\section{Funding}

This paper was not funded.

\section{Declaration of interest}

I Giles has received an unrestricted research grant, travel and consultancy fees from UCB; and publication and royalty fees from Elsevier. The authors have no other relevant affiliations or financial involvement with any organization or entity with a financial interest in or financial conflict with the subject matter or materials discussed in the manuscript apart from those disclosed.

\section{Reviewer disclosures}

Peer reviewers on this manuscript have no relevant financial or other relationships to disclose. 


\section{References:}

1. Austin HA 3rd, Klippel JH, Balow JE, et al. Therapy of lupus nephritis. Controlled trial of prednisone and cytotoxic drugs. N Engl J Med. 1986;314(10):614-19.

2. Wang CL, Wang F, Bosco JJ. Ovarian failure in oral cyclophosphamide treatment for systemic lupus erythematosus. Lupus. 1995;4(1):11-4.

3. Marder W, Fisseha S, Ganser MA, et al. Ovarian damage during chemotherapy in autoimmune diseases broad health implications beyond fertility. Clin Med Insights Reprod Health. 2012;6:9-18.

4. Ostensen M. Sexual and reproductive health in rheumatic disease. Nat Rev Rheumatol. 2017;13(8):485-93.

5. Houssiau FA, Vasconcelos C, D'Cruz D, et al. Immunosuppressive therapy in lupus nephritis the euro-lupus nephritis trial a randomized trial of low-dose versus high-dose intravenous cyclophosphamide. Arthritis Rheum. 2002;46(8):2121-31.

6. Lambertini M, Horicks F, Del Mastro L et al. Ovarian protection with gonadotropin-releasing hormone agonists during chemotherapy in cancer patients from biological evidence to clinical application. Cancer Treat Rev. 2019;72:65-77.

7. Poggio $\mathrm{F}$, Lambertini $\mathrm{M}$, Bighin $\mathrm{C}$ et al. Potential mechanisms of ovarian protection with gonadotropin-releasing hormone agonist in breast cancer patients a review. Clin Med Insights Reprod Health. 2019 [cited 2020 Jan 11]; [13 p]. DOI: 10.1177/1179558119864584.

8. Blumenfeld, Z. Fertility preservation using $\mathrm{GnRH}$ agonists rationale possible mechanisms and explanation of controversy. Clin Med Insights Reprod Health. 2019 [cited 2019 Oct 1]; [13 p.]. DOI: 10.1177/1179558119870163.

9. Marder W, McCune WJ, Wang L, et al. Adjunctive GnRH-a treatment attenuates depletion of ovarian reserve associated with cyclophosphamide therapy in premenopausal SLE patients. Gynecol Endocrinol. 2012 [cited 2018 Aug 3]; [10 p.]. DOI: 10.3109/09513590.2011.650752.

10. Massenkeil G, Alexander T, Rosen O, et al. Long-term follow-up of fertility and pregnancy in autoimmune diseases after autologous haematopoietic stem cell transplantation. Rheumatol Int. 2016;36(11):1563-8.

11. Lambertini M, Ceppi M, Poggio F, et al. Ovarian suppression using luteinizing hormone-releasing hormone agonists during chemotherapy to preserve ovarian function and fertility of breast cancer patients a meta-analysis of randomized studies. Ann Oncol. 2016;26(12):2408-19.

12. Lambertini M, Moore HCF, Leonard RCF, et al. Gonadotropin-releasing hormone agonists during chemotherapy for preservation of ovarian function and fertility in premenopausal patients with early breast cancer a systematic review and meta-analysis of individual patient-level data. J Clin Oncol. 2018;36(19):1981-90.

13. Senra JC, Roque M, Talim MCT, et al. Gonadotropin-releasing hormone agonists for ovarian protection during cancer chemotherapy systematic review and meta-analysis. Ultrasound Obstet Gynecol. 2018;51(1):77-86.

14. Clowse ME, Behera MA, Anders CK, et al. Ovarian preservation by GnRH agonists during chemotherapy a meta-analysis. J Womens Health (Larchmt). 2009 [cited 2018 Sep 10]; [10 p.]. DOI: 10.1089/jwh.2008.0857. 
15. Lambertini M, Cinquini M, Moschetti I, et al. Temporary ovarian suppression during chemotherapy to preserve ovarian function and fertility in breast cancer patients a GRADE approach for evidence evaluation and recommendations by the Italian Association of Medical Oncology. Eur J Cancer. 2017;71:25-33.

16. Oktay K, Harvey BE, Patridge AH, et al. Fertility preservation in patients with cancer ASCO clinical practice guideline update. J Clin Oncol. 2018;36(19):1994-2001.

17. Cardoso F, Kyriakides S, Ohno S, et al. Early breast cancer ESMO clinical practice guidelines for diagnosis treatment and follow-up. Ann Oncology. 2019;30(8):1194-220.

18. Paluch-Shimon S, Pagani O, Partridge AH, et al. ESO-ESMO 3rd international consensus guidelines for breast cancer in young women BCY3. Breast. 2017;35:203-17.

19. Medeiros PB, Febronio MV, Bonfa E, et al. Menstrual and hormonal alterations in juvenile systemic lupus erythematosus. Lupus. 2009;18(1):3843.

20. Aikawa NE, Sallum AM, Pereira RM, et al. Subclinical impairment of ovarian reserve in juvenile systemic lupus erythematosus after cyclophosphamide therapy. Clin Exp Rheumatol. 2012;30(3):445-9.

21. Morel N, Bachelot A, Chakhtoura Z, et al. Study of anti-mullerian hormone and its relation to the subsequent probability of pregnancy in 112 patients with systemic lupus erythematosus exposed or not to cyclophosphamide. J Clin Endocrinol Metab. 2013;98(9):3785-92.

22. Moher D, Liberati $A$, Tetzlaff $\mathrm{J}$, et al. Preferred reporting items for systematic reviews and meta-analyses the PRISMA statement. Ann Intern Med. 2009;151(4):264-9.

23. Guyatt GH, Oxman AD, Vist GE, et al. GRADE an emerging consensus on rating quality of evidence and strength of recommendations. BMJ. 2008;336(7650):924-6.

24. Baba S, Katsumata Y, Kawaguchi Y, et al. Association between low-dose pulsed intravenous cyclophosphamide therapy and amenorrhea in patients with systemic lupus erythematosus a case-control study. BMC Womens Health. 2011;11:28.

25. Martin-Suarez I, D'Cruz D, Mansoor M, et al. Immunosuppressive treatment in severe connective tissue diseases effects of low dose intravenous cyclophosphamide. Ann Rheum Dis. 1997;56(8):481-7.

26. Boumpas DT, Austin HA 3rd, Vaughan EM, et al. Risk for sustained amenorrhea in patients with systemic lupus erythematosus receiving intermittent pulse cyclophosphamide therapy. Ann Intern Med. 1993;119(5): 366-9.

27. Appenzeller S, Blatya PF, Costallat LT. Ovarian failure in SLE patients using pulse cyclophosphamide comparison of different regimes. Rheumatol Int. 2008;28(6):567-71.

28. Laskari K, Zintzaras E, Tzioufas AG. Ovarian function is preserved in women with severe systemic lupus erythematosus after a 6-month course of cyclophosphamide followed by mycophenolate mofetil. Clin Exp Rheumatol. 2010;28(1):83-6.

29. Mitwalli AH, Al Wakeel JS, Hurraib S, et al. Comparison of high and low dose of cyclophosphamide in lupus nephritis patients a long-term randomized controlled trial. Saudi J Kidney Dis Transpl. 2011;22(5):935-40. 
30. Park MC, Park YB, Jung SY, et al. Risk of ovarian failure and pregnancy outcome in patients with lupus nephritis treated with intravenous cyclophosphamide pulse therapy. Lupus. 2004;13(8):569-74.

31. Mok CC, Ying KY, Ng WL, et al. Long-term outcome of diffuse proliferative lupus glomerulonephritis treated with cyclophosphamide. Am J Med. 2006;119(4):355.e25-33.

32. McDermott EM, Powell RJ. Incidence of ovarian failure in systemic lupus erythematosus after treatment with pulse cyclophosphamide. Ann Rheum Dis. 1996;55(4):224-9.

33. Huong DL, Amoura Z, Duhaut $P$, et al. Risk of ovarian failure and fertility after intravenous cyclophosphamide a study in 84 patients. J Rheumatol. 2002;29(12):2571-6.

34. Ioannidis JP, Katsifis GE, Tzioufas AG, et al. Predictors of sustained amenorrhea from pulsed intravenous cyclophosphamide in premenopausal women with systemic lupus erythematosus. J Rheumatol. 2002;29(10):212935.

35. Belmont HM, Storch M, Buyon J, et al. New York University/Hospital for Joint Diseases experience with intravenous cyclophosphamide treatment efficacy in steroid unresponsive lupus nephritis. Lupus. 1995;4(2):104-8.

36. Bozzolo EP, Ramirez GA, Bonavida G, et al. Efficacy and toxicity of treatments for nephritis in a series of consecutive lupus patients.

Autoimmunity. 2013;46(8):537-46.

37. Silva CA, Hilario MO, Febronio MV, et al. Risk factors for amenorrhea in juvenile systemic lupus erythematosus JSLE a Brazilian multicentre cohort study. Lupus. 2007;16(7):531-6.

38. Contreras G, Tozman E, Nahar N, et al. Maintenance therapies for proliferative lupus nephritis mycophenolate mofetil azathioprine and intravenous cyclophosphamide. Lupus. 2005;14(s1):s33-8.

39. Gourley MF, Austin HA 3rd, Scott D, et al. Methylprednisolone and cyclophosphamide, alone or in combination in patients with lupus nephritis a randomized controlled trial. Ann Intern Med. 1996;125(7):549-57.

40. Gonzalez-Crespo MR, Gomez-Reino JJ, Merino R, et al. Menstrual disorders in girls with systemic lupus erythematosus treated with cyclophosphamide. $\mathrm{Br}$ J Rheumatol. 1995;34(8):737-41.

41. Langevitz $P$, Klein L, Pras $M$, et al. The effect of cyclophosphamide pulses on fertility in patients with lupus nephritis. Am J Reprod Immunol. 1992;28(34):157-8.

42. Knight JH, Howards PP, Spencer JB, et al. Characteristics related to early secondary amenorrhoea and pregnancy among women diagnosed with systemic lupus erythematosus an analysis using the GOAL study. Lupus Sci Med. 2016;3(1):e000139.

43. Kaballo BG, Ahmed AE, Nur MM, et al. Mycophenolate mofetil versus azathioprine for maintenance treatment of lupus nephritis. Saudi J Kidney Dis Transpl. 2016;27(4):717-25.

44. Singh G, Misra R, Aggarwal A. Ovarian insufficiency is major short-term toxicity in systemic lupus erythematosus patients treated with cyclophosphamide. J Assoc Physicians India. 2016;64(2):28-31.

45. Alarfaj AS, Khalil N. Fertility ovarian failure, and pregnancy outcome in SLE patients treated with intravenous cyclophosphamide in Saudi Arabia. Clin Rheumatol. 2014;33(12):1731-6. 
46. Laskari K, Mavragani CP, Tzioufas AG, et al., Mycophenolate mofetil as maintenance therapy for proliferative lupus nephritis a long-term observational prospective study. Arthritis Res Ther. 2010;12(6):R208.

47. Medeiros MM, Silveira VA, Menezes AP, et al. Risk factors for ovarian failure in patients with systemic lupus erythematosus. Braz J Med Biol Res. 2001;34(12):1561-8.

48. Singh G, Saxena N, Aggarwal A, et al. Cytochrome p450 polymorphism as a predictor of ovarian toxicity to pulse cyclophosphamide in systemic lupus erythematosus. J Rheumatol. 2007;34(4):731-3.

49. Mok CC, Lau CS, Wong RW. Risk factors for ovarian failure in patients with systemic lupus erythematosus receiving cyclophosphamide therapy. Arthritis Rheum. 1998;41(5):831-7.

50. Blumenfeld Z, Mischari O, Schultz N, et al. Gonadotropin releasing hormone agonists may minimize cyclophosphamide associated gonadotoxicity in SLE and autoimmune diseases. Semin Arthritis Rheum. 2011;41(3):346-52.

51. Somers EC, Marder W, Christman GM, et al. Use of a gonadotropin-releasing hormone analog for protection against premature ovarian failure during cyclophosphamide therapy in women with severe lupus. Arthritis Rheum. 2005;52(9):2761-7.

52. Blumenfeld Z, Shapiro D, Shteinberg $M$ et al. Preservation of fertility and ovarian function and minimizing gonadotoxicity in young women with systemic lupus erythematosus treated by chemotherapy. Lupus. 2000;9(6):401-5.

53. Uygur D, Sengul O, Bayar D, et al. Bone loss in young women with premature ovarian failure. Arch Gynecol Obstet. 2005;273(1):17-9.

54. Liao KL, Wood N, Conway GS. Premature menopause and psychological well-being. J Psychosom Obstet Gynaecol. 2000;21(3):167-74.

55. Wellons M, Ouyang P, Schreiner PJ, et al. Early menopause predicts future coronary heart disease and stroke the multi-ethnic study of atherosclerosis. Menopause. 2012;19(10):1081-7.

56. Mersereau J, Dooley MA. Gonadal failure with cyclophosphamide therapy for lupus nephritis advances in fertility preservation. Rheum Dis Clin North Am. 2010;36(1):99-108, viii.

57. Chapman RM, Sutcliffe SB. Protection of ovarian function by oral contraceptives in women receiving chemotherapy for Hodgkin's disease. Blood. 1981;58(4):849-51.

58. Elis $A$, Tevet $A$, Yerushalmi $R$, et al. Fertility status among women treated for aggressive non-Hodgkin's lymphoma. Leuk Lymphoma. 2006;47(4):623-7.

59. Brunner HI, Silva CA, Reiff A et al. Randomized double-blind dose-escalation trial of triptorelin for ovary protection in childhood-onset systemic lupus erythematosus. Arthritis Rheumatol. 2015;67(5):1377-85.

60. Births in England and Wales 2017 [Internet]. United Kingdom: Office for National Statistics; 2018 Jul [cited 2019 Oct 10]. Available from: https://www.ons.gov.uk/peoplepopulationandcommunity/birthsdeathsand marriages/livebirths/bulletins/birthsummarytablesenglandandwales/2017

61. Bidet $M$, Bachelot $A$, Bissauge $E$, et al. Resumption of ovarian function and pregnancies in 358 patients with premature ovarian failure. J Clin Endocrinol Metab. 2011;96(12):3864-72.

62. GnRH-a for ovarian protection during CYC therapy for rheumatic diseases LUPRON [Internet]. USA: National Institute of Health; 2010 Dec 10 [cited 2019 Aug 3]. Available from: https://clinicaltrials.gov/ct2/show/NCT01257802. 


\begin{tabular}{|c|c|c|c|c|c|c|c|}
\hline Author, location, year & Cohort & Study type & $\begin{array}{l}\text { Mean age, standard } \\
\text { error and range in } \\
\text { brackets (where } \\
\text { available) }\end{array}$ & $\begin{array}{l}\text { Mean dose (grams); CYC protocol if available and } \\
\text { reported as per study }\end{array}$ & $\begin{array}{l}\text { Sustained } \\
\text { amenorrhoea } \\
\text { (\% of total, } n \\
\text { in brackets) }\end{array}$ & $\begin{array}{l}\text { Hormone } \\
\text { levels } \\
\text { measured }\end{array}$ & $\begin{array}{l}\text { Strength of } \\
\text { evidence } \\
\text { using } \\
\text { GRADE } \\
\text { framework }\end{array}$ \\
\hline Baba (Japan 2011) (24) & 29 SLE & $\begin{array}{l}\text { Retrospective case } \\
\text { control study }\end{array}$ & $31(18-45)^{*}$ & $1^{*} ; 0.5 \mathrm{~g} / \mathrm{body} / \mathrm{pulse}$ & $12.5(4)$ & No & Low \\
\hline $\begin{array}{l}\text { Martin-Suarez (UK } \\
\text { 1997) (25) }\end{array}$ & $\begin{array}{l}43 \text { SLE; } 19 \text { GPA; } \\
12 \text { USV; } 11 \text { PAN, } \\
\text { MPA or EGPA; } 4 \\
\text { IIM; } 1 \text { MEC }\end{array}$ & $\begin{array}{l}\text { Retrospective cohort } \\
\text { study }\end{array}$ & $\begin{array}{l}\text { Not reported for females } \\
\text { alone }\end{array}$ & $\begin{array}{l}\text { Not reported for females alone; } 0.5 \mathrm{~g} \text { weekly until } \\
\text { complete/partial remission, then } 0.5 \mathrm{~g} \text { monthly or } \\
\text { switch to azathioprine }\end{array}$ & $0(0)$ & No & Low \\
\hline $\begin{array}{l}\text { Boumpas (short) + } \\
\text { (USA 1993) (26) }\end{array}$ & $16 \mathrm{SLE}$ & $\begin{array}{l}\text { Retrospective case } \\
\text { control study }\end{array}$ & $27 \pm 1.6$ & $\begin{array}{l}\text { Not reported; } 0.5 \text { to } 1.0 \mathrm{~g} / \mathrm{m}^{2} \text { body surface area } \\
\text { monthly } x 7\end{array}$ & $12.5(2)$ & No & Low \\
\hline $\begin{array}{l}\text { Appenzeller (group B) + } \\
\text { (Canada 2008) (27) }\end{array}$ & 50 SLE & $\begin{array}{l}\text { Retrospective cohort } \\
\text { study }\end{array}$ & $\begin{array}{l}21.8 \pm 0.92(15-36) \text { group } \\
\text { B }\end{array}$ & $\begin{array}{l}\text { No data on whole cohort; } 0.5 \mathrm{mg} / \mathrm{body} \text { surface and } \\
\text { increased when necessary }\end{array}$ & $0(0)$ & $\begin{array}{l}\text { FSH, LH, PRL, } \\
\text { oestradiol } \\
\text { measured but } \\
\text { specific results } \\
\text { not provided }\end{array}$ & Low \\
\hline $\begin{array}{l}\text { Laskari (group 2) + } \\
(\text { Greece 2010) (28) }\end{array}$ & 22 SLE & $\begin{array}{l}\text { Retrospective cohort } \\
\text { study }\end{array}$ & $28 \pm 7.34(14-45)$ & $8.1 \pm 1.6 ; 1 \mathrm{~g} / \mathrm{m}^{2}$ monthly $\times 5-7$ & $4.5(1)$ & No & Low \\
\hline $\begin{array}{l}\text { Mitwalli (group 2) }+ \\
\text { (Saudi Arabia 2011) } \\
\text { (29) }\end{array}$ & 39 SLE & $\begin{array}{l}\text { Randomised double } \\
\text { blind controlled trial }\end{array}$ & $\begin{array}{l}\text { Not reported for females } \\
\text { alone }\end{array}$ & $\begin{array}{l}\text { Not reported; } 5 \mathrm{mg} / \mathrm{kg} \text { body weight monthly } \mathrm{x} 6 \text {, then } 2 \\
\text { monthly } \times 18\end{array}$ & $15.4(6)$ & No & High \\
\hline $\begin{array}{l}\text { Mitwalli (group 1) + } \\
\text { (Saudi Arabia 2011) } \\
\text { (29) }\end{array}$ & $61 \mathrm{SLE}$ & $\begin{array}{l}\text { Randomised double } \\
\text { blind controlled trial }\end{array}$ & $\begin{array}{l}\text { Not reported for females } \\
\text { alone }\end{array}$ & $\begin{array}{l}\text { Not reported; } 10 \mathrm{mg} / \mathrm{kg} \text { body weight monthly } \mathrm{x} 6 \text {, then } 2 \\
\text { monthly } \times 6\end{array}$ & $41.5(25)$ & No & High \\
\hline $\begin{array}{l}\text { Park (South Korea } \\
2004)(30)\end{array}$ & 67 SLE nephritis & $\begin{array}{l}\text { Retrospective cohort } \\
\text { study }\end{array}$ & $31.1 \pm 8.4$ (range $17-46)$ & $\begin{array}{l}8.4 \pm 3.0 \text { (menstruating) } \\
9.4 \pm 2.2 \text { (sustained amenorrhoea) } \\
8.6 \text { (combined); } 0.5-0.75 \mathrm{~g} / \mathrm{m}^{2} \text { monthly } x 6 \text {, then } 3 \\
\text { monthly } x 6\end{array}$ & $17.9(12)$ & No & Low \\
\hline $\begin{array}{l}\text { Mok A (Hong Kong } \\
\text { 2006) (31) }\end{array}$ & 99 SLE & $\begin{array}{l}\text { Retrospective cohort } \\
\text { study }\end{array}$ & $\begin{array}{l}\text { Not reported for females } \\
\text { alone }\end{array}$ & $\begin{array}{l}\text { Not reported for females alone; } 0.5-1 \mathrm{~g} / \mathrm{m}^{2} \text { body } \\
\text { surface area monthly } \mathrm{x} 6 \text {, then } 3 \text { monthly } x 6\end{array}$ & $13.1(13)$ & $\begin{array}{l}\text { FSH, } \\
\text { oestradiol } \\
\text { measured but } \\
\text { specific results } \\
\text { not provided }\end{array}$ & Low \\
\hline $\begin{array}{l}\text { Langevitz (Israel 1992) } \\
\text { (41) }\end{array}$ & $17 \mathrm{SLE}$ & $\begin{array}{l}\text { Prospective cohort } \\
\text { study }\end{array}$ & $29.4(14-45)$ & $\begin{array}{l}6.3 \text { (menstruating) } \\
7.0 \text { (premature menopause) } \\
6.1 \text { (combined); } 10 \mathrm{mg} / \mathrm{kg} \text { monthly, or every } 1-2 \mathrm{wk} \\
\text { followed by monthly pulses }\end{array}$ & $23.5(4)$ & No & Low \\
\hline $\begin{array}{l}\text { Blumenfeld (Israel } \\
\text { 2011) (50) }\end{array}$ & $\begin{array}{l}8 \text { SLE, } 1 \text { Behcet's, } \\
1 \text { JIA, } 1 \text { SSc }\end{array}$ & $\begin{array}{l}\text { Retrospective case } \\
\text { control study }\end{array}$ & $29.4 \pm 5.82(23-39)$ & 10.4 ; monthly pulses $x 6$ then 3 monthly pulses $x 8$ & $45.4(5)$ & $\begin{array}{l}\text { FSH, LH, } \\
\text { oestradiol, } \\
\text { progesterone } \\
\text { measured but } \\
\text { specific results } \\
\text { not provided }\end{array}$ & Low \\
\hline $\begin{array}{l}\text { Huong (France 2002) } \\
\text { (33) }\end{array}$ & $56 \mathrm{SLE}$ & $\begin{array}{l}\text { Retrospective and } \\
\text { prospective cohort } \\
\text { study }\end{array}$ & $\begin{array}{l}28 \pm 9(13-53) \\
26 \pm 8(13-45) \\
\text { (menstruating) } \\
37 \pm 7(30-53) \text { (sustained } \\
\text { amenorrhoea) }\end{array}$ & $\begin{array}{l}11.5 ; 0.5-1 \mathrm{~g} / \text { pulse with mean number of pulses } 13+/- \\
6.5 \text {, duration between pulses not reported }\end{array}$ & $23.2(13)$ & No & Low \\
\hline $\begin{array}{l}\text { Gonzalez-Crespo } \\
\text { (Spain 1995) (40) }\end{array}$ & $10 \mathrm{SLE}$ & $\begin{array}{l}\text { Retrospective case } \\
\text { control study }\end{array}$ & $13 \pm 2$ & $\begin{array}{l}\left.13.0^{*} \text { (range } 6.4-24\right) ; 0.5-1.2 \mathrm{~g} / \mathrm{m}^{2} \text { body surface with } \\
\text { mean duration of } 27+/-13 \text { months of treatment, } \\
\text { duration between pulses not reported }\end{array}$ & $0(0)$ & No & Low \\
\hline
\end{tabular}




\begin{tabular}{|c|c|c|c|c|c|c|c|}
\hline $\begin{array}{l}\text { Mcdermott (England } \\
\text { 1996) (32) }\end{array}$ & $35 \mathrm{SLE}$ & $\begin{array}{l}\text { Retrospective cohort } \\
\text { study }\end{array}$ & $36.1(17-49)$ & $\begin{array}{l}11.8 \text { (menstruating) } \\
16.8 \text { (sustained amenorrhoea) } \\
14.5 \text { (combined); } 1 \mathrm{~g} \text { weekly } \times 4 \text {, then fortnightly } \times 4 \text {, } \\
\text { then monthly } x 3\end{array}$ & $54(19)$ & $\begin{array}{l}\mathrm{FSH}, \\
\text { oestradiol } \\
\text { measured but } \\
\text { specific results } \\
\text { not provided }\end{array}$ & Low \\
\hline $\begin{array}{l}\text { Somers (USA 2005) } \\
\text { (51) }\end{array}$ & $20 \mathrm{SLE}$ & $\begin{array}{l}\text { Prospective cohort } \\
\text { study }\end{array}$ & $25 \pm 0.9$ & $\begin{array}{l}12.9 \pm 1.5 ; 0.5 \mathrm{~g} / \mathrm{m}^{2} \text { body surface area monthly } \times 6 \text { with } \\
\text { subsequent doses increased by up to } 25 \% \text { depending } \\
\text { on WCC, then switched to azathioprine or } \\
\text { mycophenolate mofetil or monthly CYC } \times 4\end{array}$ & $30(6)$ & $\begin{array}{l}\text { FSH } \\
\text { measured in } \\
\text { patients with } \\
\text { suspected POI } \\
\text { but specific } \\
\text { results not } \\
\text { provided }\end{array}$ & Moderate \\
\hline $\begin{array}{l}\text { loannidis (Greece 2002) } \\
\text { (34) }\end{array}$ & 67 SLE & $\begin{array}{l}\text { Retrospective cohort } \\
\text { study }\end{array}$ & $27^{*}(22-35)$ & $\begin{array}{l}14.6^{*}(\mathrm{IQR} 9.0-21.75) ; 0.75-1 \mathrm{~g} / \mathrm{m}^{2} \text { monthly } \times 6, \text { then } \\
2 \text { monthly } \times 6,3 \text { monthly } \times 4 \text {, then ceased or spaced at } \\
\text { even longer intervals }\end{array}$ & $31.3(21)$ & No & Low \\
\hline $\begin{array}{l}\text { Appenzeller (group A) + } \\
\text { (Canada 2008) (27) }\end{array}$ & 57 SLE & $\begin{array}{l}\text { Retrospective cohort } \\
\text { study }\end{array}$ & $20 \pm 7.8(16-38)$ & $\begin{array}{l}\text { No data on whole cohort } \\
16.8 \mathrm{~g} \pm 2.8 \text { (range } 14-20 \text { ) (Group A sustained } \\
\text { amenorrhoea) } \\
13.4 \mathrm{~g} \pm 1.8 \text { (range } 11-15 \text { ) (Group A transient } \\
\text { amenorrhoea; } 0.75 \mathrm{mg} / \text { body surface and increased } \\
\text { when necessary }\end{array}$ & $17.5(10)$ & $\begin{array}{l}\text { FSH, LH, PRL, } \\
\text { oestradiol } \\
\text { measured but } \\
\text { specific results } \\
\text { not provided }\end{array}$ & Low \\
\hline $\begin{array}{l}\text { Bozzolo (Italy 2013) } \\
\text { (36) }\end{array}$ & 29 SLE nephritis & $\begin{array}{l}\text { Retrospective cohort } \\
\text { study }\end{array}$ & $\begin{array}{l}28.6 \pm 8.7 \text { (menstruating) } \\
32.7 \pm 4.7 \text { (POF) } \\
29.5 \text { (combined) }\end{array}$ & $\begin{array}{l}13.4 \pm 5.7 \text { (menstruating) } \\
20.8 \pm 6.4 \text { (POF) } \\
14.9 \text { (combined); } 0.75-1 \mathrm{~g} / \mathrm{m}^{2} \text { monthly } x 6-11 \text {, then } \\
\text { maintenance therapy of } 3 \text { monthly pulses, azathioprine } \\
\text { or mycophenolate mofetil }\end{array}$ & $20.7(6)$ & No & Low \\
\hline $\begin{array}{l}\text { Laskari (Group 1) + } \\
\text { (Greece 2010) (28) }\end{array}$ & 39 SLE & $\begin{array}{l}\text { Retrospective cohort } \\
\text { study }\end{array}$ & $30.2 \pm 8.73(14-46)$ & $\begin{array}{l}20.1 \pm 7 ; 1 \mathrm{~g} / \mathrm{m}^{2} \text { monthly } \times 6, \text { then } 2 \text { monthly } \times 6, \\
3 \text { monthly } x 4 \text { and then at even longer intervals based } \\
\text { on response }\end{array}$ & $51(20)$ & No & Low \\
\hline $\begin{array}{l}\text { Boumpas (long) + (USA } \\
\text { 1993) (26) }\end{array}$ & $23 \mathrm{SLE}$ & $\begin{array}{l}\text { Retrospective case } \\
\text { control study }\end{array}$ & $25 \pm 1.5$ & Not reported; $0.5-1 \mathrm{~g} / \mathrm{m}^{2}$ body surface area $\times 15$ & $39.1(9)$ & No & Low \\
\hline $\begin{array}{l}\text { Belmont (USA 1995) } \\
(35)\end{array}$ & $27 \mathrm{SLE}$ & $\begin{array}{l}\text { Retrospective cohort } \\
\text { study }\end{array}$ & Not reported & $\begin{array}{l}\text { Not reported for females alone; } 0.5-1 \mathrm{~g} / \mathrm{m}^{2} \text { body } \\
\text { surface area monthly } \mathrm{x} 6 \text { then } 3 \text { monthly until } \\
\text { satisfactory response or irreversible deterioration of } \\
\text { renal function }\end{array}$ & $\begin{array}{l}11.1(3)-\text { all } \\
\text { females }>27 \\
\text { years old }\end{array}$ & No & Low \\
\hline $\begin{array}{l}\text { Gourley (USA 1996) } \\
\text { (39) }\end{array}$ & 46 SLE nephritis & $\begin{array}{l}\text { Randomised } \\
\text { controlled study }\end{array}$ & Not reported & Not reported; $0.75 \mathrm{~g} / \mathrm{m}^{2}$ monthly $\mathrm{x} 6$, then 3 monthly $\times 8$ & $50(23)$ & No & High \\
\hline $\begin{array}{l}\text { Contreras (USA 2005) } \\
\text { (38) }\end{array}$ & 18 SLE nephritis & $\begin{array}{l}\text { Randomised } \\
\text { controlled trial }\end{array}$ & $\begin{array}{l}\text { Not reported for females } \\
\text { alone }\end{array}$ & $\begin{array}{l}\text { Not reported for females alone; } 0.5-1 \mathrm{~g} / \mathrm{m}^{2} \text { body } \\
\text { surface area monthly up to } \mathrm{x} 7 \text {, then for maintenance } \\
\text { therapy } 0.5-1 \mathrm{~g} / \mathrm{m}^{2} \text { 3monthly, azathioprine or } \\
\text { mycophenolate mofetil }\end{array}$ & $33.3(6)$ & No & High \\
\hline Knight (USA 2016) (42) & 33 SLE & $\begin{array}{l}\text { Retrospective cross- } \\
\text { sectional study }\end{array}$ & Not reported & Not reported; protocol not reported & $39(13)$ & No & Low \\
\hline $\begin{array}{l}\text { Massenkeil (Germany } \\
\text { 2016) (10) }\end{array}$ & $\begin{array}{l}5 \text { SLE, } 2 \text { SSc, } 1 \\
\text { RPC, } 1 \\
\text { panniculitis, } 1 \text { TA, } \\
1 \text { GPA }\end{array}$ & $\begin{array}{l}\text { Prospective cohort } \\
\text { study }\end{array}$ & $33.4 \pm 3.2(22-48)$ & $12.9 \pm 2.7 ;$ protocol not reported & $27.3(3)$ & $\begin{array}{l}\text { FSH, LH, } \\
\text { oestradiol } \\
\text { measured - all } \\
3 \text { patients with } \\
\text { sustained } \\
\text { amenorrhoea } \\
\text { had elevated } \\
\text { FSH before } \\
\text { CYC exposure }\end{array}$ & Low \\
\hline
\end{tabular}




\begin{tabular}{|c|c|c|c|c|c|c|c|}
\hline $\begin{array}{l}\text { Kaballo (Sudan 2016) } \\
\text { (43) }\end{array}$ & 75 SLE nephritis & $\begin{array}{l}\text { Randomised control } \\
\text { trial }\end{array}$ & $\begin{array}{l}\text { Not reported for females } \\
\text { alone }\end{array}$ & Not reported; $0.5 \mathrm{~g} / \mathrm{m}^{2}$ monthly $\times 6$ & $0(0)$ & $\begin{array}{l}\mathrm{FSH}, \mathrm{LH} \\
\text { measured but } \\
\text { specific results } \\
\text { not provided }\end{array}$ & High \\
\hline $\begin{array}{l}\text { Singh G (India 2016) } \\
\text { (44) }\end{array}$ & 34 SLE & $\begin{array}{l}\text { Retrospective cross- } \\
\text { sectional study }\end{array}$ & $\begin{array}{l}29.7 \pm 9.95 \text { (8-67) for } \\
\text { entire study (not } \\
\text { reported for IV CYC } \\
\text { exposed group alone or } \\
\text { females alone) }\end{array}$ & $\begin{array}{l}\text { Not reported for females alone; } 0.5-0.75 \mathrm{~g} / \mathrm{m}^{2} \text { monthly } \\
x 6 \text {, then } 3 \text { monthly } x 6\end{array}$ & $17.6(6)$ & No & Low \\
\hline $\begin{array}{l}\text { Alarfaj (Saudi Arabia } \\
\text { 2014) (45) }\end{array}$ & 99 SLE & $\begin{array}{l}\text { Retrospective cohort } \\
\text { study }\end{array}$ & 29.8 & $\begin{array}{l}7.1 ; 10 \mathrm{mg} / \mathrm{kg} \text { monthly } \mathrm{x} 6 \text {, then } 2 \text { monthly } \mathrm{x} 6 \text {, or } 5 \mathrm{mg} / \mathrm{kg} \\
\mathrm{x} 6 \text { then } 2 \text { monthly } \mathrm{x} 18\end{array}$ & $13.1(13)$ & No & Low \\
\hline $\begin{array}{l}\text { Houssiau (high dose) }+ \\
\text { (Europe 2002) (5) }\end{array}$ & 43 SLE nephritis & $\begin{array}{l}\text { Randomised control } \\
\text { trial }\end{array}$ & $\begin{array}{l}\text { Not reported for females } \\
\text { alone }\end{array}$ & $\begin{array}{l}8.5 \pm 1.9 ; 0.5 \mathrm{~g} / \mathrm{m}^{2} \text { then increased by } 0.25 \mathrm{~g} / \mathrm{m}^{2} \text { up to } \\
\max 1.5 \mathrm{~g} / \mathrm{m}^{2} \text { monthly } x 6 \text { then } 3 \text { monthly } x 2\end{array}$ & $2.3(1)$ & No & High \\
\hline $\begin{array}{l}\text { Houssiau (low dose) + } \\
\text { (Europe 2002) (5) }\end{array}$ & 41 SLE nephritis & $\begin{array}{l}\text { Randomised control } \\
\text { trial }\end{array}$ & $\begin{array}{l}\text { Not reported for females } \\
\text { alone }\end{array}$ & $3 ; 0.5 \mathrm{~g}$ fortnightly $\times 6$ & $4.9(2)$ & No & High \\
\hline $\begin{array}{l}\text { Laskari (Greece 2010) } \\
\text { (46) }\end{array}$ & 28 SLE & $\begin{array}{l}\text { Prospective cohort } \\
\text { study }\end{array}$ & $\begin{array}{l}\text { Not reported for females } \\
\text { alone }\end{array}$ & Not reported; $1 \mathrm{~g} / \mathrm{m}^{2}$ monthly pulses $\times 5-7$ & $4(1)$ & No & Low \\
\hline $\begin{array}{l}\text { Medeiros MMC (Brazil } \\
\text { 2001) (47) }\end{array}$ & 26 SLE & $\begin{array}{l}\text { Retrospective cohort } \\
\text { study }\end{array}$ & 28.5 & $12.5 ; 0.5-1 \mathrm{~g} / \mathrm{m}^{2}$ monthly $\times 7$ then $1 \mathrm{~g} / \mathrm{m}^{2}$ 3monthly $\times 6-8$ & $34.6(9)$ & $\begin{array}{l}\text { FSH, LH, PRL, } \\
\text { oestradiol, } \\
\text { progesterone, } \\
\text { testosterone } \\
\text { measured but } \\
\text { results not } \\
\text { reported for } \\
\text { those on IV } \\
\text { CYC alone }\end{array}$ & Low \\
\hline $\begin{array}{l}\text { Medeiros PB (Brazil } \\
\text { 2009) (19) }\end{array}$ & 13 juvenile SLE & $\begin{array}{l}\text { Retrospective cohort } \\
\text { study }\end{array}$ & $\begin{array}{l}\text { Not reported for IV CYC } \\
\text { alone }\end{array}$ & Not reported; protocol not reported & $0(0)$ & $\begin{array}{l}\text { FSH, LH, PRL, } \\
\text { oestradiol, } \\
\text { progesterone, } \\
\text { testosterone } \\
\text { measured but } \\
\text { results not } \\
\text { reported for } \\
\text { those on IV } \\
\text { CYC alone }\end{array}$ & Low \\
\hline Singh (India 2007) (48) & 35 SLE & $\begin{array}{l}\text { Prospective cohort } \\
\text { study }\end{array}$ & $24.5 \pm 8.5$ & $\begin{array}{l}\text { 9.34 } \pm 2.87 \text {; at least } 6 \text { pulses of CYC (dose/pulse not } \\
\text { specified) }\end{array}$ & $31.4(11)$ & No & Low \\
\hline $\begin{array}{l}\text { Mok CC (Hong Kong } \\
\text { 1998) (49) }\end{array}$ & $16 \mathrm{SLE}$ & $\begin{array}{l}\text { Retrospective cohort } \\
\text { study }\end{array}$ & $\begin{array}{l}\text { Not specified for IV CYC } \\
\text { alone }\end{array}$ & $\begin{array}{l}6.9 \pm 3.8 \text { (SEM); } 0.5-1 \mathrm{~g} / \mathrm{m}^{2} \text { monthly } x 6 \text { then 3monthly } \\
x 6\end{array}$ & $12.5(2)$ & $\begin{array}{l}\mathrm{FSH}, \mathrm{LH}, \\
\text { oestradiol } \\
\text { measured but } \\
\text { results not } \\
\text { reported for } \\
\text { those on IV } \\
\text { CYC alone }\end{array}$ & Low \\
\hline
\end{tabular}




\begin{tabular}{|c|c|c|c|c|c|c|c|}
\hline $\begin{array}{l}\text { Blumenfeld (Israel } \\
\text { 2000) (52) }\end{array}$ & 6 SLE & $\begin{array}{l}\text { Prospective cohort } \\
\text { study }\end{array}$ & 28.2 & $13.3 ; 0.75$ or $1 \mathrm{~g} /$ pulse monthly $\mathrm{x} 6$ & $66.6(4)$ & $\begin{array}{l}\text { FSH, LH, } \\
\text { oestradiol, } \\
\text { progesterone } \\
\text { measured but } \\
\text { specific results } \\
\text { not provided }\end{array}$ & Low \\
\hline
\end{tabular}

Table 1: Studies assessing the risk of sustained amenorrhoea after treatment with intravenous cyclophosphamide for autoimmune rheumatic disease

Table 1 showing the studies included in the systematic review, which assessed sustained amenorrhoea in patients with autoimmune rheumatic disease treated with intravenous cyclophosphamide.

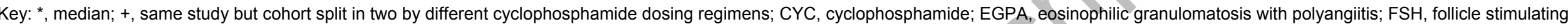
hormone; GRADE, Grading of Recommendations, Assessment, Development and Evaluations; GPA, granulomatosis with polyangiitis; IIM, idiopathic inflammatory myopathy; IQR, interquartile range; IV, intravenous; JIA, juvenile idiopathic arthritis; LH, lutenising hormone; MEC, mixed essential cryoglobulinaemia; MPA, microscopic polyangiitis; PAN, polyarteritis nodosa; POF, premature ovarian failure; PRL, prolactin; RPC, relapsing polychondritis; SEM, standard error of the mean; SLE, systemic lupus erythematosus; SSc, systemic sclerosis; TA, Takayasu's arteritis; USV undifferentiated systemic vasculitis; WCC, white cell count. 
Table 2: Studies assessing the effect of GnRHa treatment alongside intravenous cyclophosphamide (CYC) for autoimmune rheumatic disease on incidence of sustained amenorrhoea compared to intravenous CYC alone

\begin{tabular}{|c|c|c|c|c|c|c|c|}
\hline $\begin{array}{l}\text { Author } \\
\text { and } \\
\text { Location }\end{array}$ & Cohort & Study Type & $\begin{array}{l}\text { Gnrh Dosing and } \\
\text { Timing }\end{array}$ & CYC Dosing & $\begin{array}{l}\text { Outcome } \\
\text { Measure }\end{array}$ & $\begin{array}{l}\text { Results and Follow } \\
\text { Up }\end{array}$ & $\begin{array}{l}\text { Additional Information } \\
\text { and Grading of } \\
\text { Evidence }\end{array}$ \\
\hline $\begin{array}{l}\text { Blumenfeld } \\
\text { et al, Israel } \\
(50)\end{array}$ & $\begin{array}{l}\text { 34 SLE, } 5 \text { systemic } \\
\text { sclerosis, } 2 \text { mixed } \\
\text { connective tissue } \\
\text { disease, } 1 \\
\text { polyarteritis nodosa, } \\
1 \text { Behcets, } 1 \\
\text { juvenile idiopathic } \\
\text { arthritis } \\
31 \text { GnRHa vs } 11 \\
\text { control (excluding } 2 \\
\text { patients lost to } \\
\text { follow-up) } \\
\text { Mean age 25.6 } \pm 5.3 \\
\text { years (16-38) } \\
\text { GnRHa group vs } \\
30.1 \pm 5.5 \text { years (23- } \\
39 \text { ) control group }\end{array}$ & $\begin{array}{l}\text { Retrospective } \\
\text { case control }\end{array}$ & $\begin{array}{l}\text { Decapeptyl CR, } \\
3.75 \text { mg monthly } \\
\text { starting before } \\
\text { CYC and } \\
\text { continued during } \\
\text { treatment, up to } \\
6 x\end{array}$ & $\begin{array}{l}\text { Monthly IV CYC } \\
\text { ("standard regime") } \\
\text { x6 - then } 3 \text { monthly } \\
\text { x8. Further } \\
\text { treatment dependent } \\
\text { on disease e.g. SLE } \\
\text { relapses treated with } \\
\text { additional } 4 \text { monthly } \\
\text { boluses of CYC. } \\
\text { Mean cumulative } \\
\text { CYC dose } 8.92 \mathrm{~g} \\
\text { GnRHa group vs } \\
8.72 \mathrm{~g} \text { control group } \\
\text { (after adjusting } \\
\text { groups to include } \\
\text { only patients who } \\
\text { received up to 15g) }\end{array}$ & $\begin{array}{l}\text { Premature } \\
\text { ovarian failure } \\
\text { (POF) based } \\
\text { on } \\
\text { amenorrhoea, } \\
\text { hormonal } \\
\text { profile (FSH, } \\
\text { LH, estradiol, } \\
\text { progesterone), } \\
\text { ultrasound of } \\
\text { ovaries and } \\
\text { endometrium, } \\
\text { and } \\
\text { conceptions 1- } \\
10 \text { years post } \\
\text { treatment }\end{array}$ & $\begin{array}{l}\text { POF in } 1 / 31 \mathrm{GnRHa} \\
\text { group vs } 5 / 11 \text { control } \\
\text { group } \\
\text { OR } 0.0400(95 \% \mathrm{Cl} \\
0.0039 \text { to } 0.4067, \\
p=0.0065)\end{array}$ & $\begin{array}{l}\text { 1/31 in GnRHa group } \\
\text { who developed POF } \\
\text { was aged } 37 \\
5 / 11 \text { controls who } \\
\text { developed POF had } \\
\text { mean age of } 32.2 \pm 7.2 \\
\text { When adjusted for age } \\
\text { and dose differences, } \\
\text { POF rate in control } \\
\text { group remained } 40 \% \text {, } \\
\text { significantly higher than } \\
\text { in GnRHa group, p<0.05 } \\
7 \text { successful } \\
\text { pregnancies and } 1 \\
\text { miscarriage in GnRHa } \\
\text { group vs } 3 \text { successful } \\
\text { pregnancies in control } \\
\text { group } \\
\text { Grade of evidence: low }\end{array}$ \\
\hline
\end{tabular}




\begin{tabular}{|c|c|c|c|c|c|c|c|}
\hline $\begin{array}{l}\text { Somers et } \\
\text { al, USA } \\
(51)\end{array}$ & $\begin{array}{l}\text { SLE } \\
20 \text { GnRHa vs } 20 \\
\text { control } \\
\text { Age } \leq 35 \text { years and } \\
\text { no symptoms } \\
\text { suggestive of POF. } \\
\text { Mean age } 23.9 \pm 1.0 \\
\text { years GnRHa group } \\
\text { vs } 25 \pm 0.9 \text { years } \\
\text { control group (range } \\
17-32 \text { ) }\end{array}$ & $\begin{array}{l}\text { Retrospective } \\
\text { analysis for } \\
\text { controls, } \\
\text { prospective } \\
\text { for } \mathrm{GnRHa} \\
\text { group. } \\
\text { Age }( \pm 5 \\
\text { years) and } \\
\text { dose }( \pm 5 \mathrm{~g}) \\
\text { matched }\end{array}$ & $\begin{array}{l}\text { Monthly depot } \\
\text { leuprolide acetate } \\
3.75 \mathrm{mg} \text { at least } \\
10 \text { days prior to } \\
\text { CYC dose }\end{array}$ & $\begin{array}{l}\text { IV monthly CYC x6 } \\
\pm 4 \text { monthly boluses } \\
\text { if still active } \\
\text { Mean cumulative } \\
\text { CYC dose } \\
12.9 \mathrm{~g} \pm 1.5 \mathrm{~g} \text { in both } \\
\text { groups }\end{array}$ & $\begin{array}{l}\text { POF defined } \\
\text { as } \\
\text { amenorrhea } \\
\geq 12 \text { months } \\
\text { and FSH } \geq 40 \\
\mathrm{mlU} / \mathrm{ml}\end{array}$ & $\begin{array}{l}\text { POF in } 1 / 20 \mathrm{GnRHa} \\
\text { group vs } 6 / 20 \text { control } \\
\text { group } \\
\text { OR } 0.1228(95 \% \mathrm{Cl} \\
0.0132 \text { to } 1.1384, \\
p=0.0649)\end{array}$ & $\begin{array}{l}\text { Follow up minimum } 3 \\
\text { years } \\
\text { GnRHa treated patient } \\
\text { with POF age } 28.2 \\
\text { years and } 33.5 \mathrm{~g} \\
\text { Unknown how many } \\
\text { women attempted } \\
\text { conception after CYC } \\
\text { treatment. } 3 / 20 \text { control } \\
\text { patients (15\%) and } 7 / 20 \\
\text { GnRHa (35\%) } \\
\text { successful pregnancies. } \\
\text { Grade of evidence: low }\end{array}$ \\
\hline $\begin{array}{l}\text { Blumenfeld } \\
\text { et al, Israel } \\
(52)\end{array}$ & $\begin{array}{l}\text { SLE } \\
5 \text { GnRHa vs } 6 \\
\text { controls } \\
\text { Mean age } 25.6 \\
\text { years GnRHa group } \\
\text { vs } 28.2 \text { years } \\
\text { control group (range } \\
20-43 \text { ) }\end{array}$ & $\begin{array}{l}\text { Prospective } \\
\text { cohort study }\end{array}$ & $\begin{array}{l}\text { Monthly depot } \\
\text { decapeptyl CR } \\
3.75 \mathrm{mg} \text { in parallel } \\
\text { with CYC for up to } \\
6 \text { months }\end{array}$ & $\begin{array}{l}\text { IV monthly CYC } \\
\text { Mean cumulative } \\
\text { CYC dose } 7.7 \mathrm{~g} \\
\text { GnRHa group ( } 2 \\
\text { patients' data } \\
\text { missing) vs } 13.3 \mathrm{~g} \\
\text { control (1 patient's } \\
\text { data missing) }\end{array}$ & $\begin{array}{l}\text { POF defined } \\
\text { as } \\
\text { amenorrhoea } \\
\text { (4-15 years } \\
\text { post } \\
\text { treatment), } \\
\text { estradiol } \\
<100 \text { pmol/L, } \\
\text { FSH }>\text { LH, } \\
\text { FSH }>25 I U / L\end{array}$ & $\begin{array}{l}\text { POF in } 0 / 5 \mathrm{GnRHa} \\
\text { group vs } 4 / 6 \text { control } \\
\text { group } \\
\text { OR } 0.0505(95 \% \mathrm{Cl} \\
0.0019 \text { to } 1.3450, \\
p=0.0746)\end{array}$ & $\begin{array}{l}\text { Follow up minimum } 4 \\
\text { years } \\
\text { Grade of evidence: low }\end{array}$ \\
\hline
\end{tabular}

Table 2 comparing the three studies included in the systematic review that compared outcomes for patients on intravenous CYC and GnRHa treatment to those on intravenous $\mathrm{CYC}$ alone. The pooled odds ratio of ovarian dysfunction with $\mathrm{GnRHa}$ and cyclophosphamide compared to cyclophosphamide alone was 0.054 (95\% $\mathrm{Cl}$ $0.0115-0.2576 p=0.0002$, z-statistic 3.668), corresponding to a number needed to treat (NNT) of $2.7(95 \% \mathrm{Cl} 1.955-4.388$ ) and an absolute risk reduction of $36.95 \%$ (95\% Cl 35.6-38.4\%).

Key: $\mathrm{Cl}$, confidence interval; $\mathrm{CR}$, controlled release; CYC, cyclophosphamide; FSH, follicle stimulating hormone; GnRHa, gonadotropin releasing hormone agonist; $\mathrm{LH}$, lutenising hormone; SLE, systemic lupus erythematosus; POF, premature ovarian failure; OR, odds ratio. 


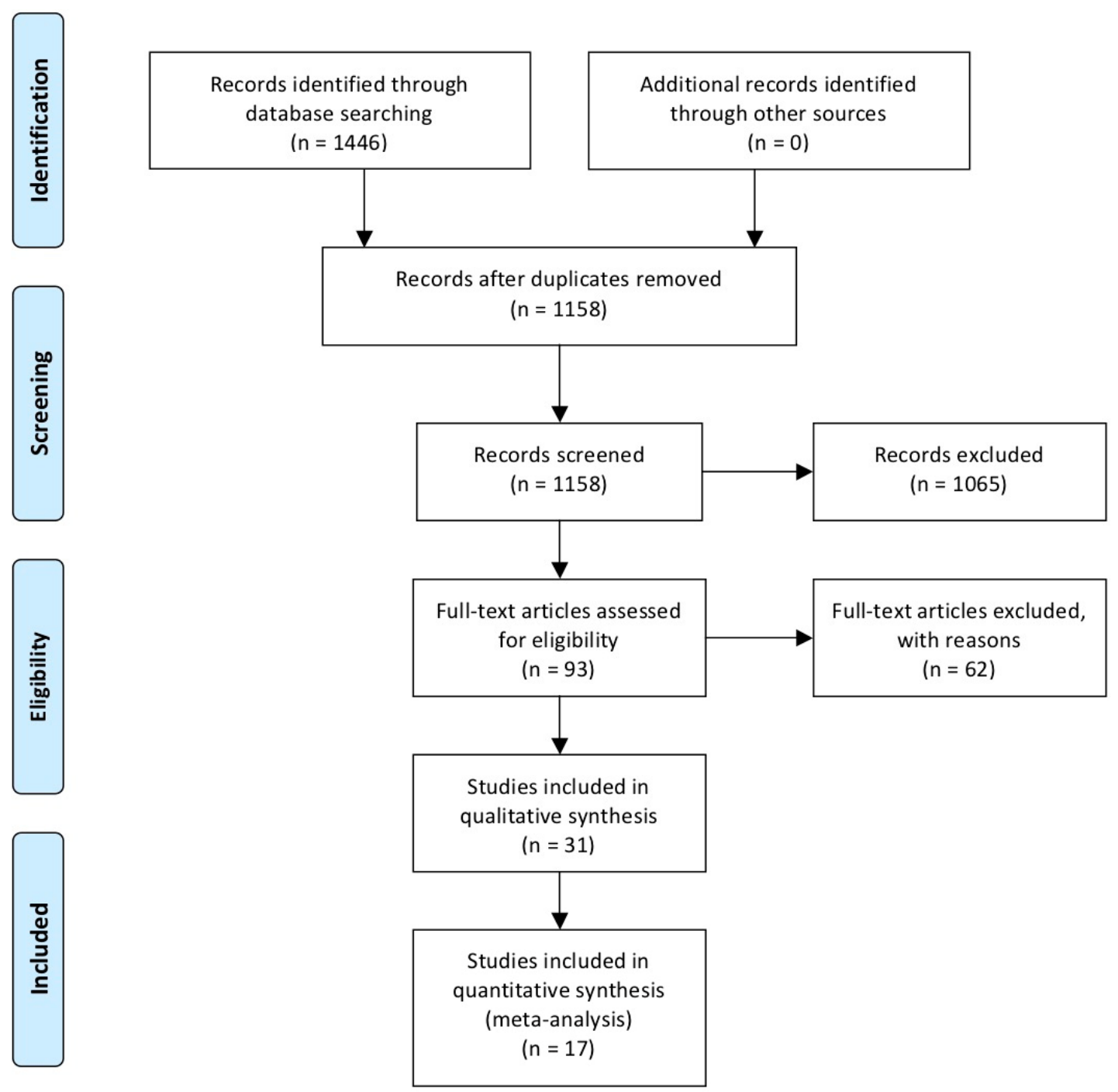

Figure 1. Flowchart of Study Selection for Systematic Review and Meta-Analysis of the Gonadotoxic Effects of Cyclophosphamide and Benefits of GnRHa in Women of Child-bearing Age with Autoimmune Rheumatic Disease

PRISMA diagram displaying the methodology of selecting studies for the systematic review and metaanalysis.

Adapted From: Moher D, Liberati A, Tetzlaff J, Altman DG, The PRISMA Group (2009). Preferred Reporting Items for Systematic Reviews and Meta-Analyses: The PRISMA Statement. PLoS Med 6(7): e1000097. doi:10.1371/journal.pmed1000097 


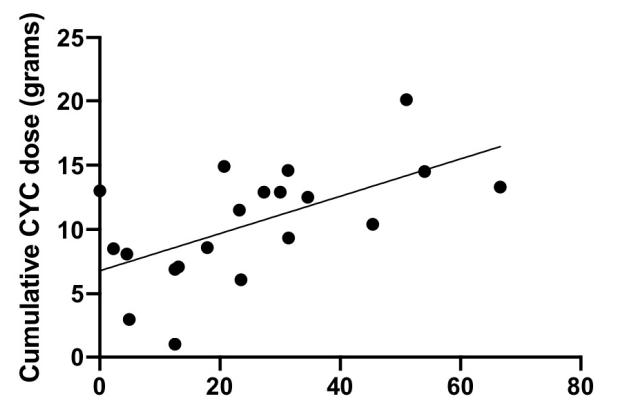

Rate of sustained amenorrhoea for each study (\%)

Figure 2. Rate of Sustained Amenorrhoea vs Cumulative Cyclophosphamide Dose.

The graph shows the rate of sustained amenorrhoea and the cumulative cyclophosphamide dose in individual studies.

Key: CYC, cyclophosphamide 


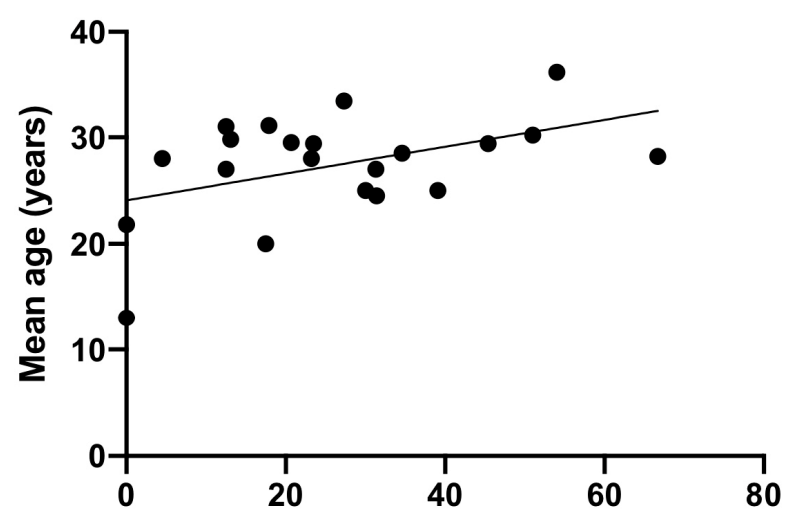

Rate of sustained amenorrhoea for each study (\%)

Figure 3. Rate of Sustained Amenorrhoea vs Mean Age.

Graph shows the rate of sustained amenorrhoea and corresponding mean age in individual studies included in the systematic review. 


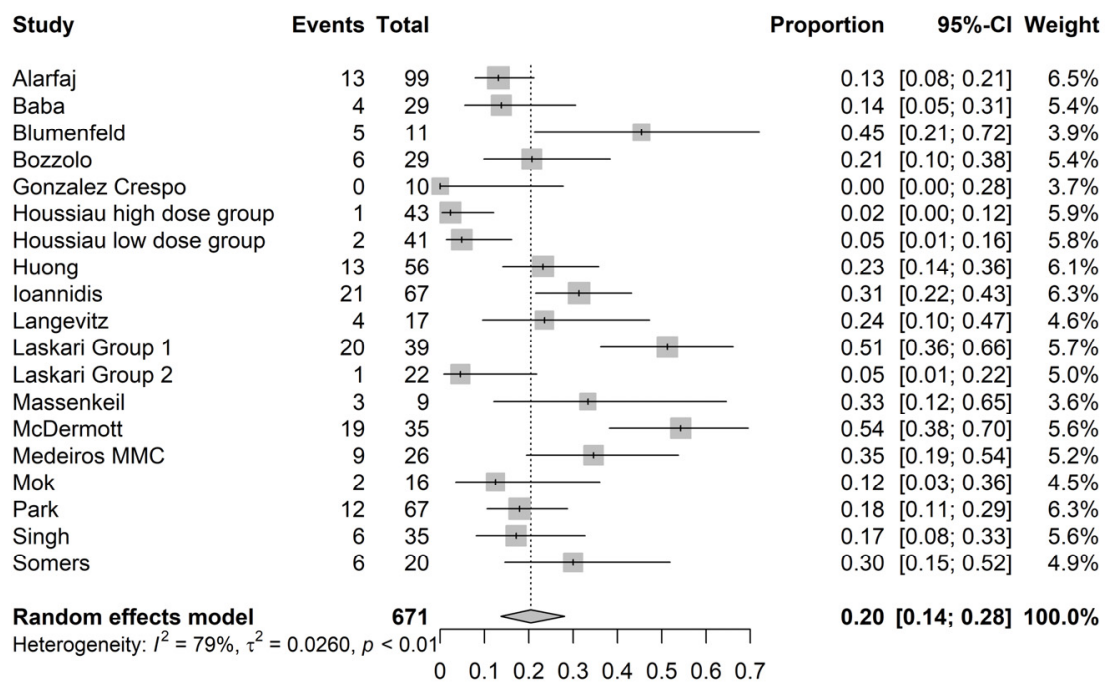

Figure 4. Forest Plot of Studies Included in Meta-Analysis Showing Proportion of Sustained Amenorrhoea.

Forest plot displaying the proportion of sustained amenorrhoea in individual studies included in the meta-analysis. Events refer to the number of patients who developed sustained amenorrhoea, and the total refers to the total number of patients in each study. 


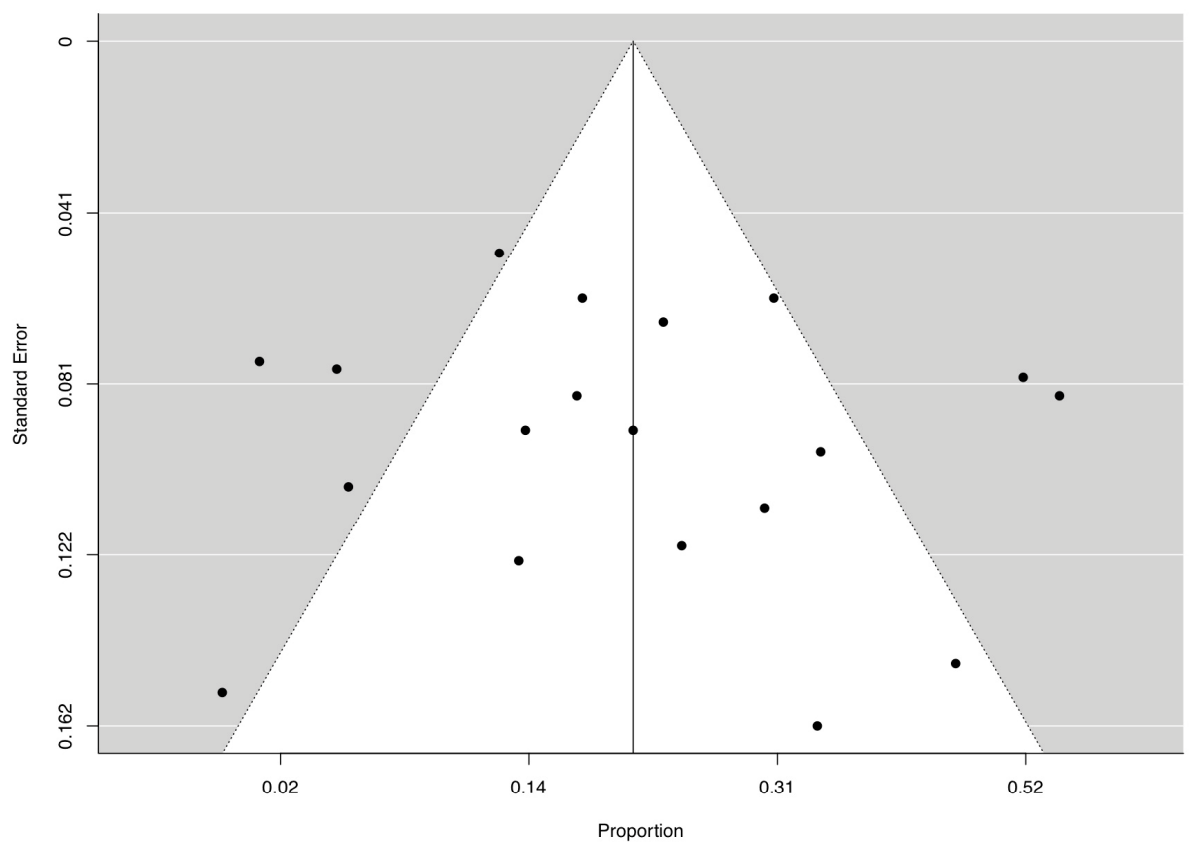

Figure 5. Funnel Plot of Studies Included in Meta-analysis.

Funnel plot with each dot representing a study (note two studies have two subgroups and therefore two dots each); the y-axis represents the study precision (standard error); and the $x$-axis shows the studv's result (proportion of sustained amenorrhoea). 